\title{
Fibroblast growth factor-23 regulates parathyroid hormone and $1 \alpha$-hydroxylase expression in cultured bovine parathyroid cells
}

\author{
Tijana Krajisnik1 , Peyman Björklund², Richard Marsell ${ }^{2}$, Östen Ljunggren ${ }^{1}$, Göran Åkerström² \\ Kenneth B Jonsson ${ }^{2}$, Gunnar Westin ${ }^{2}$ and Tobias E Larsson ${ }^{1}$
}

Departments of ${ }^{1}$ Medical Sciences and ${ }^{2}$ Surgical Sciences, Uppsala University Hospital, 75185 Uppsala, Sweden

(Correspondence should be addressed to T E Larsson; Email: tobias.larsson@medsci.uu.se)

\begin{abstract}
Fibroblast growth factor-23 (FGF23) is a circulating factor that decreases serum levels of inorganic phosphate $(\mathrm{Pi})$ as well as 1,25-dihydroxyvitamin $\mathrm{D}_{3}$. Recent studies also suggest a correlation between serum levels of FGF23 and parathyroid hormone (PTH) in patients with chronic kidney disease. It is, however, unknown whether FGF23 directly modulates PTH expression, or whether the correlation is secondary to abnormalities in Pi and vitamin D metabolism. The objective of the current study was therefore to elucidate possible direct effects of FGF23 on bovine parathyroid cells in vitro. Treatment of parathyroid cells with a stabilized form of recombinant FGF23 (FGF23(R176Q)) induced a rise in early response gene-1 mRNA transcripts, a marker of FGF23 signaling. FGF23(R176Q) potently and dose-dependently
\end{abstract}

decreased the PTH mRNA level within $12 \mathrm{~h}$. In agreement, FGF23(R176Q) also decreased PTH secretion into conditioned media. In contrast, FGF23(R176Q) dose-dependently increased $1 \alpha$-hydroxylase expression within $3 \mathrm{~h}$. FGF23 (R176Q) did not affect cell viability nor induce apoptosis, whereas a small but significant increase in cell proliferation was found. We conclude that FGF23 is a negative regulator of PTH mRNA expression and secretion in vitro. Our data suggest that FGF23 may be a physiologically relevant regulator of PTH. This defines a novel function of FGF23 in addition to the previously established roles in controlling vitamin D and Pi metabolism.

Journal of Endocrinology (2007) 195, 125-131

\section{Introduction}

Fibroblast growth factor-23 (FGF23) is a circulating phosphaturic factor that plays a critical role in renal phosphate $(\mathrm{Pi})$ reabsorption and vitamin D metabolism (ADHR-Consortium 2000, Shimada et al. 2001). Its physiological importance is exemplified by numerous activating and inactivating mutations in the human FGF23 gene, causing two clinical disorders of disturbed Pi homeostasis: autosomal dominant hypophosphatemic rickets (ADHR, OMIM\#193100; ADHR-Consortium 2000) and hyperphosphatemic familial tumoral calcinosis (HFTC, OMIM\#211900; Benet-Pages et al. 2005, Larsson et al. 2005). Elevated FGF23 levels are also associated with several other disorders of hypophosphatemia or dysfunctional regulation of vitamin $\mathrm{D}$, such as autosomal recessive hypophosphatemic rickets (ARHR; Feng et al. 2006, Lorenz-Depiereux et al. 2006), X-linked hypophosphatemic rickets (XLH; Liu et al. 2003, Riminucci et al. 2003), tumor-induced osteomalacia (TIO; Shimada et al. 2001, White et al. 2001b), fibrous dysplasia (FD; Riminucci et al. 2003), and linear nevus sebaceous syndrome (LNSS; Hoffman et al. 2005).

The regulation of $\mathrm{Pi}$ and the production of 1,25dihydroxyvitamin $\mathrm{D}_{3}\left(1,25(\mathrm{OH})_{2} \mathrm{D}_{3}\right)$ mainly occur in the kidney, although the physiological source of FGF23 production is bone (Riminucci et al. 2003, Mirams et al. 2004, Sitara et al. 2004). In states of hyperphosphatemia, such as in chronic kidney disease (CKD) and hypoparathyroidism, FGF23 expression is induced, giving rise to increased serum FGF23 levels (Larsson et al. 2003a, Gupta et al. 2004). The compensatory rise in FGF23 causes a decrease in renal Pi reabsorption and diminished production of $1,25(\mathrm{OH})_{2} \mathrm{D}_{3}$ due to decreased expression of 25-hydroxyvitamin $\mathrm{D}_{3}-1 \alpha-$ hydroxylase $(1 \alpha(\mathrm{OH})$ ase; Shimada et al. 2001). Serum levels of FGF23 continuously increase as renal function declines in CKD (Imanishi et al. 2004, Larsson et al. 2004, Shigematsu et al. 2004), at least in part, due to the manifest hyperphosphatemia. In end-stage renal disease (ESRD), FGF23 concentrations are therefore typically increased a 1000-fold or more when compared with healthy individuals (Imanishi et al. 2004, Larsson et al. 2004, Shigematsu et al. 2004). Elevated FGF23 in CKD has been proposed to play a role in the development of secondary hyperparathyroidism (Kazama et al. 2005, Nakanishi et al. 2005).

Recent studies have shed light on FGF23 signaling. It has been demonstrated that Klotho is a permissive receptor cofactor for FGF23, converting FGFR1 (IIIc) into a native FGF23-specific receptor (Urakawa et al. 2006). Klotho null mice also display a marked elevation of serum Fgf23, although 
their phenotype closely resembles that of Fgf23 knockout mice, presenting further evidence of Klotho as a regulator of FGF23 signaling (Kurosu et al. 2006, Urakawa et al. 2006). Importantly, Klotho is abundantly expressed in parathyroid glands (Ito et al. 2007). This has raised the question whether FGF23 may exert direct effects on parathyroid glands. In a physiological context, a relationship between FGF23 and PTH is also plausible due to their overlapping capacity to diminish renal Pi reabsorption and counter-regulatory effects on $1 \alpha(\mathrm{OH})$ ase. Finally, a covariation of FGF23 and PTH has been observed in vivo in early and late stages of $\mathrm{CKD}$ (Shigematsu et al. 2004, Westerberg et al. 2007).

In the current study, we sought to elucidate potential regulatory effects of FGF23 on PTH and $1 \alpha(\mathrm{OH})$ ase expression in vitro, using bovine parathyroid cells.

\section{Materials and Methods}

Preparation of bovine parathyroid glands and cell culture

Bovine parathyroid glands were obtained from healthy adult cattle within minutes after slaughter as previously described (Segersten et al. 2002). The glands were minced with scissors and cell suspensions were prepared by collagenase digestion at $37^{\circ} \mathrm{C}$ in a shaking incubator in F-10 medium $(\mathrm{pH} \mathrm{7.4)}$ containing $1 \mathrm{mg} / \mathrm{ml}$ collagenase, $0.05 \mathrm{mg} / \mathrm{ml}$ DNase I, $1.25 \mathrm{mM} \mathrm{CaCl}_{2}$, and $1.5 \%$ BSA. The incubation was carried out for $2 \mathrm{~h}$, interrupted by repeated pipette aspirations. After filtration through a nylon mesh, cells were centrifuged through $25 \%$ standard isotonic Percoll (Pharmacia Biotech). Cell viability was determined by Trypan blue staining before seeding into six-well plates. In each well, $0 \cdot 5 \times 10^{6}$ cells were seeded in Dulbecco's modified Eagle's medium (DMEM)-medium containing 10\% fetal calf serum (FCS) and penicillin-fungizone plus L-glutamine (PFL). Cells were grown in an incubator at $37^{\circ} \mathrm{C}$ in $5 \% \mathrm{CO}_{2}$ and FGF23(R176Q) treatment was initiated after $24 \mathrm{~h}$. Validations of the experimental system revealed that approximately $95 \%$ of cultured cells are stained positive for PTH (Knutson et al. 1998) and display an inverse relationship between intracellular calcium concentration and PTH secretion (Segersten et al. 2002).

\section{COS- 7 cell culture}

COS-7 cells were grown in $75 \mathrm{ml}$ flasks in a total volume of $15 \mathrm{ml}$ DMEM medium with $10 \%$ FCS supplemented with PFL. The cells were kept in an incubator at $37^{\circ} \mathrm{C}, 5 \% \mathrm{CO}_{2}$.

\section{Recombinant FGF23 protein production}

The cDNA encoding full-length human FGF23 was cloned into the pcDNA3.1-V5-His-TOPO plasmid (Larsson et al. 2003b). A mutation encoding the FGF23(R176Q) protein was introduced into the plasmid using site-directed mutagenesis as previously described (Larsson et al. 2003b). FGF23(R176Q) protein was used in all experiments in order to increase protein stability (White et al. 2001a). hFGF23(R176Q)-pcDNA3.1-V5-His-TOPO plasmid and an empty mock pcDNA3.1 $(+)$ plasmid as control were transfected into COS-7 cells using FuGENE 6 Transfection Reagent (Roche Diagnostics Scandinavia AB). Conditioned serum-free medium from transfected COS-7 cells was collected 3-4 days after transfection. FGF23 concentrations were determined by ELISA measurements (Yamazaki et al. 2002). All FGF23-containing conditioned media were diluted to appropriate experimental concentrations using the mock-transfected control conditioned media as diluent. FGF23 protein was added to the bovine parathyroid cells as diluted serum-free conditioned media. Each experiment was performed in triplicates and repeated two to four times.

\section{$R N A$ extraction}

In accordance with EZNA Total RNA Isolation Protocol (Omega Biotek, Doraville, GA, USA), total RNA was extracted and on-membrane DNase I digestion was performed. Electrophoresis on 1\% agarose gel was run to check for RNA degradation. NanoDrop ND-1000 Spectrophotometer (NanoDrop Technologies, Wilmington, DE, USA) was used to estimate concentration as well as to obtain the purity $\mathrm{A}_{260} / \mathrm{A}_{280}$ ratio (>1.99). A representative group of samples was further analyzed by Agilent 2100 Bioanalyzer (Agilent Technologies, Santa Clara, CA, USA) to confirm adequate RNA integrity. RNA was kept at $-70{ }^{\circ} \mathrm{C}$.

\section{cDNA synthesis}

Superscript II Reverse Transcriptase and Oligo (dT)-primers (Invitrogen) were used for reverse transcription from 0.6-1 $\mu \mathrm{g}$ total DNased RNA. cDNA was kept at $-20{ }^{\circ} \mathrm{C}$.

\section{Real-time PCR analysis}

A total volume of $25 \mu \mathrm{l}$ per PCR was used: $12 \cdot 5 \mu \mathrm{l}(2 \times)$ iQ SYBR Green Supermix containing fluorescein (Bio-Rad); $2.5 \mu \mathrm{l}(2 \mu \mathrm{M})$ Primer Fwd; $2.5 \mu \mathrm{l}(2 \mu \mathrm{M})$ Primer Rev; $5.5 \mu \mathrm{l}$ sterile $\mathrm{H}_{2} \mathrm{O}$; and $2 \mu \mathrm{cDNA}$. The iCycler, MyiQ Single Color Real-Time PCR Detection System (Bio-Rad) was used and the cycling conditions were: a) $95^{\circ} \mathrm{C}, 3 \mathrm{~min}$; b) 40 times: $95^{\circ} \mathrm{C}$, $15 \mathrm{~s} ; 54-60^{\circ} \mathrm{C}$ ( $T_{\mathrm{a}}$ depending on the primers), $\left.1 \mathrm{~min} ; \mathrm{c}\right) 95^{\circ} \mathrm{C}$, $1 \mathrm{~min}$; d) $55^{\circ} \mathrm{C}, 1 \mathrm{~min}$; and e) 80 times: $+0 \cdot 5^{\circ} \mathrm{C}$, starting from $55^{\circ} \mathrm{C}, 10 \mathrm{~s}$, for melt-curve determination. All samples, including non-template negative controls, were amplified in duplicates. All assays were run three to four times. The sequences of bovine PTH and GAPDH primer pairs have previously been described (Segersten et al. 2002). Primer sequences for bovine $1 \alpha(\mathrm{OH})$ ase were as follows: F: $5^{\prime}$-ATCCCCAAAAATACGCTGGT-3' and R: $5^{\prime}$-GCTGGACGAAAAGAATTTGG-3' .

Relative gene expression was calculated according to the comparative $C_{\mathrm{t}}$ method $\left(2^{-\Delta \Delta \mathrm{Ct}}\right)$ by Livak \& Schmittgen (2001). 


\section{ELISA measurements}

To determine FGF23 protein concentration, conditioned media from transfected COS-7 cells were analyzed by an intact FGF23 ELISA (Kainos laboratories, Tokyo, Japan; Yamazaki et al. 2002). This ELISA detects only the intact, biologically active, portion of the protein. For measurement of secreted PTH protein, a bovine intact PTH ELISA was used (Immutopics, San Clemente, CA, USA) according to the manufacturer's instructions. To determine PTH protein secretion, parathyroid cells were treated at various concentrations of FGF23 for $24 \mathrm{~h}$, followed by two $1 \times$ PBS washes and addition of fresh serum-free medium to the cells. After $4 \mathrm{~h}$, conditioned media were collected for subsequent PTH measurements. Secreted PTH concentrations were corrected for total protein content in the wells, determined using a NanoDrop ND-1000 Spectrophotometer. Secreted protein levels were measured from triplicate wells in two separate experiments.

\section{Flow cytometry analysis}

Parathyroid cells were trypsinized and diluted with $1 \times$ PBS and divided into two $5 \mathrm{ml}$ FACS tubes (measured in duplicates). The cells were centrifuged, washed by, and resuspended in FACS buffer: $2 \% \mathrm{FCS}, 0 \cdot 05 \% \mathrm{NaN}_{3}, 2 \cdot 5 \mathrm{mM} \mathrm{CaCl}_{2}$, and $1 \times \mathrm{PBS}$. After a second centrifugation, the cells were resuspended in $100 \mu \mathrm{l}$ FACS buffer, and $5 \mu \mathrm{l}$ anti-Annexin V-FITC-conjugated antibodies were added. They were left for 20-30 min in darkness at room temperature. After a second wash, $5 \mu \mathrm{l}$ propidium iodide (PI) was added. Non-treated cells were used as FACS controls: a) without FITC or PI, b) only FITC, and c) only PI. Low flow speed and a limit of 50000 cells were set for each measurement. Identical settings were used at later measurements. Total apoptosis was defined as the sum of early (FITC) and late (FITC and PI) apoptosis. FACS results were derived from two separate experiments.

\section{Tritium-labeled thymidine incorporation}

In order to estimate the proliferation of the cells, $1 \mu \mathrm{Ci}$ $\left[{ }^{3} \mathrm{H}\right]$ thymidine was added to each well $12 \mathrm{~h}$ before harvesting. After incubation, medium was removed and unincorporated $\left[{ }^{3} \mathrm{H}\right]$ thymidine was precipitated with $500 \mu \mathrm{l}$ cold trichloracetic acid for $20 \mathrm{~min}$. This procedure was repeated twice. Cells were then lysed in $1 \mathrm{ml} 10 \% \mathrm{NaOH}$ and $0 \cdot 5 \%$ Triton X. The radioactivity was measured in a $\beta$-counter. Proliferation data were obtained from three separate experiments and all samples were run in triplicates.

\section{Statistical analysis}

GraphPad Prism Version 3.03 software (GraphPad Software Inc., San Diego, CA, USA) was used for statistical data analysis. Unpaired $t$-tests were performed, and the results are shown as arithmetic means \pm s.E.M. A $P$ value of $<0 \cdot 05$ was considered statistically significant.

\section{Results}

Homology analysis of human and bovine FGF23 revealed $83 \%$ identity at the nucleotide level and $84 \%$ identity at the amino acid level (data not shown). Functionally important motifs, such as the ${ }^{176} \mathrm{RXXR}^{179}$ site (ADHR-Consortium 2000), were preserved allowing human recombinant FGF23 protein to be used in the experiments. In addition, we used mutant FGF23(R176Q) protein in all experiments in order to increase FGF23 stability (White et al. 2001a). The short-term biological potency of FGF23(R176Q) and wild-type FGF23 are similar based on previous studies on renal $\mathrm{Pi}$ transport (Shimada et al. 2002). To determine the effect of FGF23 on parathyroid cells, we used a well-established system of primary isolates of bovine parathyroid cells.

As expected, we found by RT-PCR that the FGF23 receptor cofactor Klotho was expressed in the parathyroid cells as previously reported in mice (Ito et al. 2007; data not shown). To further validate our assay system, we analyzed the effect of FGF23(R176Q) treatment on the Egr-1 mRNA expression, a reported marker of FGF23 signaling (Urakawa et al. 2006). FGF23(R176Q) treatment evoked an increase in Egr-1 mRNA after $60 \mathrm{~min}$, suggesting a direct effect of FGF23(R176Q) on parathyroid cells (Fig. 1).

Subsequently, we determined the effect of FGF23(R176Q) on PTH mRNA expression. At $400 \mathrm{pg} / \mathrm{ml}$ (equivalent to approximately $286 \mathrm{nM}$ ) FGF23(R176Q), the PTH mRNA level was significantly decreased $(P<0 \cdot 05)$ when compared with control-treated cells at $12 \mathrm{~h}$ (Fig. 2a) as determined by real-time RT-PCR. The maximal observed effect was detected at $24 \mathrm{~h}(P<0 \cdot 01)$ and sustained for at least $48 \mathrm{~h}$

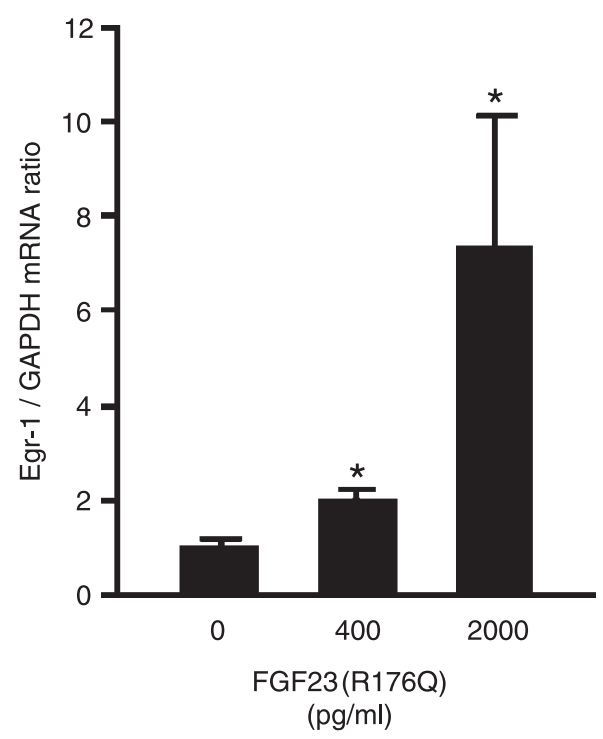

Figure 1 Egr-1 is an early response gene and a marker of FGF23 signaling. A rise in Egr-1 mRNA was observed 60 min after treatment with 400 and $2000 \mathrm{pg} / \mathrm{ml}$ FGF23(R176Q), supporting a direct effect of FGF23 on parathyroid cells. Error bars indicate mean \pm S.E.M. 

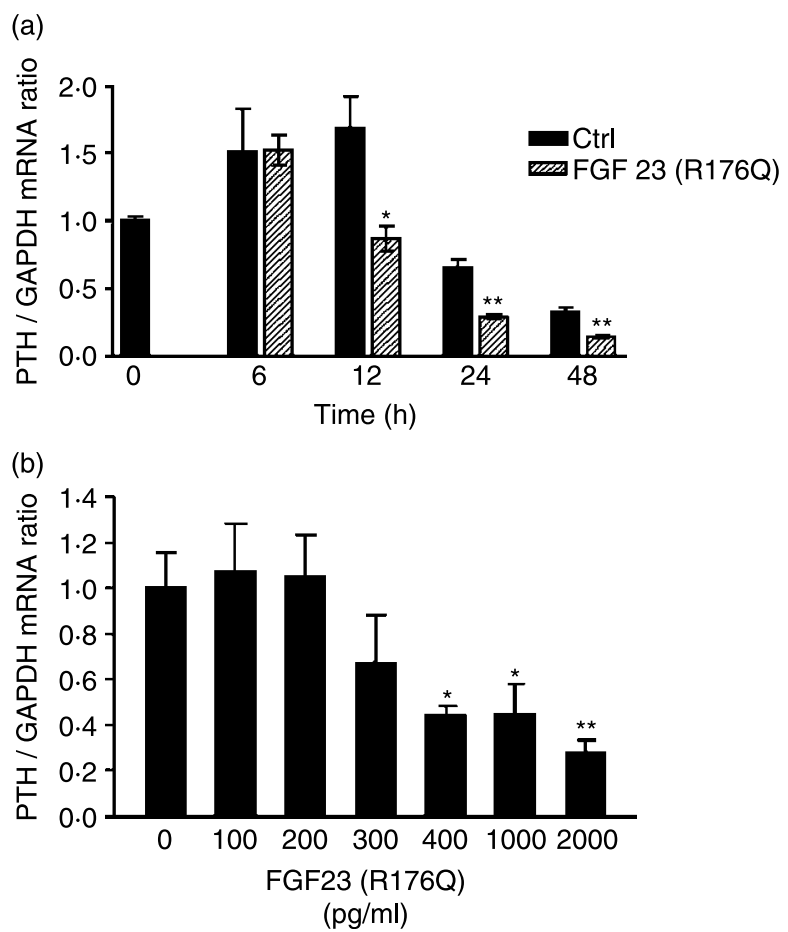

Figure 2 (a) FGF23(R176Q) decreased the expression of PTH mRNA in bovine parathyroid cells when compared with controltreated cells. A significant difference was observed after $12 \mathrm{~h}$ of FGF23(R176Q) treatment and sustained for $48 \mathrm{~h}$. Cells were treated with $400 \mathrm{pg} / \mathrm{ml} \mathrm{FGF23(R176Q).}{ }^{*} P<0 \cdot 05 ;{ }^{* *} P<0 \cdot 01$. Error bars indicate mean \pm S.E.M. (b) FGF23(R176Q) dose-dependently decreased PTH mRNA in bovine parathyroid cells at $24 \mathrm{~h}$. A significant reduction in PTH mRNA level was observed at $400 \mathrm{pg} / \mathrm{ml}$ FGF23(R176Q). ${ }^{*} P<0 \cdot 05 ;{ }^{*} P<0 \cdot 01$. Error bars indicate mean \pm s.E.M.

$(P<0 \cdot 01$; Fig. 2 a). In order to determine the concentrations required for reducing the $\mathrm{PTH}$ mRNA level, we treated the parathyroid cells for $24 \mathrm{~h}$ at various concentrations of FGF23(R176Q), ranging from 100 to $2000 \mathrm{pg} / \mathrm{ml}$ (Fig. 2b). FGF23(R176Q) reduced the PTH mRNA level in a dose-dependent manner (Fig. 2b) in the concentration range of $400-2000 \mathrm{pg} / \mathrm{ml}$. To exclude the possibility that control-conditioned media (from mock-transfected cells) regulated the PTH mRNA level, we performed a doseresponse treatment with control-conditioned media serially diluted in nonconditioned media. This revealed no effect on PTH mRNA expression (data not shown). In summary, our data suggest that FGF23(R176Q) dose-dependently decreases the PTH mRNA level.

We further examined whether FGF23(R176Q) displayed a regulatory effect on $\mathrm{PTH}$ secretion. For this purpose, conditioned media from FGF23(R176Q)- and controltreated parathyroid cells were analyzed for PTH concentrations, using a bovine intact PTH ELISA. Importantly, FGF23(R176Q) dose-dependently decreased the secretion of PTH protein at $24 \mathrm{~h}$ when compared with control-treated cells in the concentration range of $700-2000 \mathrm{pg} / \mathrm{ml}$ (Fig. 3).

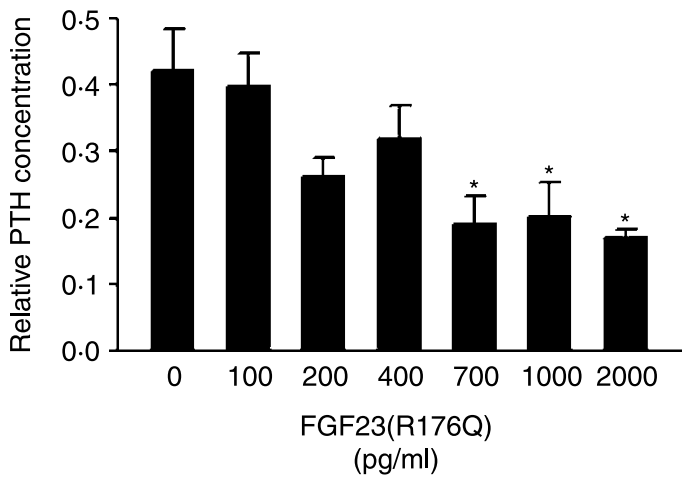

Figure 3 FGF23(R176Q) dose-dependently decreased PTH secretion. A significant reduction in extracellular PTH protein level was detected at $700 \mathrm{pg} / \mathrm{ml} \mathrm{FGF23(R176Q).} \mathrm{PTH} \mathrm{was}$ measured using a bovine PTH ELISA after $24 \mathrm{~h}$ of FGF23(R176Q) stimulation and subsequent incubation in fresh medium for $4 \mathrm{~h}$. $* P<0 \cdot 05$. Error bars indicate mean \pm s.E.M.

Since several previous studies have shown that FGF23 decreases the expression of $1 \alpha(\mathrm{OH})$ ase expression in kidneys (Shimada et al. 2001, 2002, 2004a,b,c, Bai et al. 2004, Larsson et al. 2004, Sitara et al. 2004), we investigated the effect of FGF23(R176Q) treatment on parathyroid $1 \alpha(\mathrm{OH})$ ase expression. Notably, FGF23(R176Q) increased $1 \alpha(\mathrm{OH})$ ase mRNA level within $3 \mathrm{~h}$ and the effect sustained for $24 \mathrm{~h}$ (Fig. 4a). The effect was dose dependent in the concentration range of 400-2000 pg/ml (Fig. 4b).

We also examined parathyroid cell number, viability, apoptosis, and proliferation. At a FGF23(R176Q) concentration of $2000 \mathrm{pg} / \mathrm{ml}$ for $24 \mathrm{~h}$, we did not observe significant effects on total cell number (data not shown) or viability (Fig. 5a) when compared with control-treated cells. Similarly, we did not detect any significant effect on apoptosis (Fig. 5b), whereas a small but significant increase in cell proliferation was observed (Fig. 5c). The proportion of cells expressing $\mathrm{PTH}$ was $\sim 90-95 \%$ at $0-48 \mathrm{~h}$, independent of FGF23(R176Q) treatment (data not shown).

\section{Discussion}

Previous extensive studies have shown that FGF23 is a key regulator of Pi and vitamin D metabolism (ADHR-Consortium 2000, Shimada et al. 2001). Maintenance of mineral ion homeostasis is a complex process involving several hormonal systems and target tissues, including bone, kidney, and parathyroid glands. Observational data supporting a correlation between FGF23 and PTH in vivo (Shigematsu et al. 2004, Kazama et al. 2005, Nakanishi et al. 2005), and the presence of the FGF23 receptor cofactor Klotho in parathyroid glands (Ito et al. 2007) prompted us to elucidate whether FGF23 directly modulates PTH expression in parathyroid cells. Herein, we demonstrate that FGF23(R176Q) induced a dose-dependent decrease in PTH mRNA level and protein secretion. Our data support a previously unidentified direct link between FGF23 
(a)
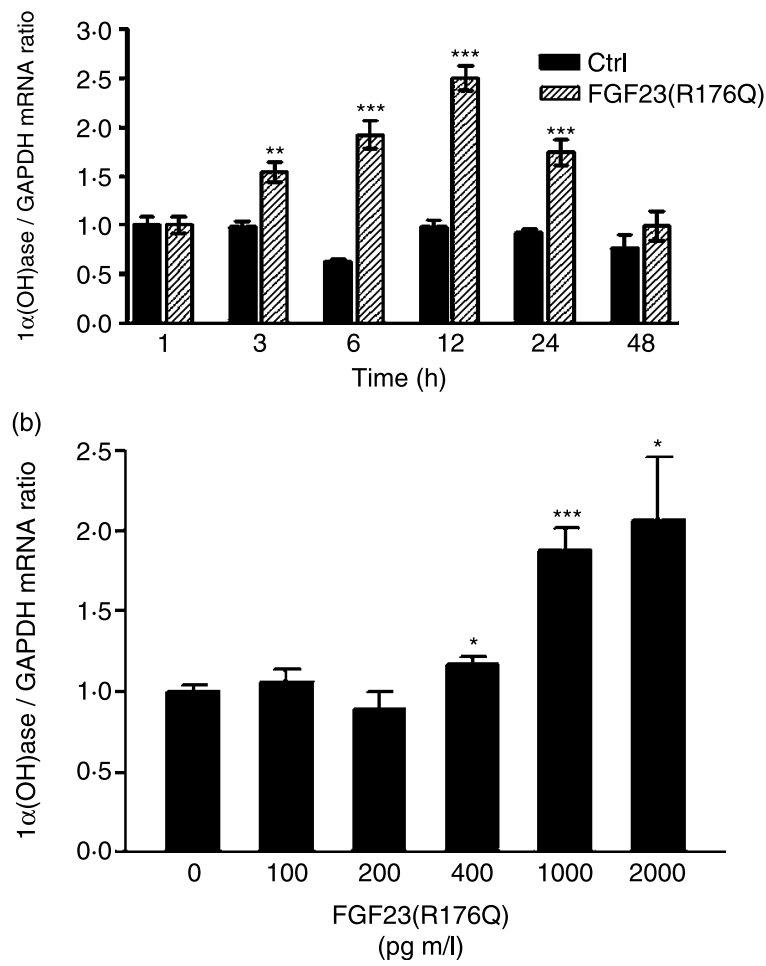

Figure 4 (a) FGF23(R176Q) increased the expression of $1 \alpha(\mathrm{OH})$ ase mRNA in bovine parathyroid cells when compared with controltreated cells. A significant difference was observed within $3 \mathrm{~h}$ of FGF23(R176Q) treatment and sustained for $24 \mathrm{~h}$. Cells were treated with $1000 \mathrm{pg} / \mathrm{ml} \mathrm{FGF23(R176Q).}{ }^{* *} P<0 \cdot 01 ;{ }^{* * *} P<0 \cdot 001$. Error bars indicate mean \pm s.E.M. (b) FGF23(R176Q) dose-dependently increased $1 \alpha(\mathrm{OH})$ ase mRNA level at $24 \mathrm{~h}$. A significant rise in $1 \alpha(\mathrm{OH})$ ase mRNA level was observed at $400 \mathrm{pg} / \mathrm{ml}$ FGF23(R176Q). $* P<0.05 ; P<0 \cdot 001$. Error bars indicate mean \pm S.E.M.

and PTH. Because we used an isolated in vitro system, we were able to clarify direct FGF23-mediated effects on PTH expression, as opposed to secondary systemic changes in mineral metabolism.

To evaluate direct effects of FGF23 on parathyroid cells, we investigated expression levels of Egr-1, a marker of FGF23 signaling (Urakawa et al. 2006). In agreement with previous reports, we observed a rise in Egr-1 as early as $1 \mathrm{~h}$ after FGF23(R176Q) treatment. In contrast, we noted a significant decrease in PTH mRNA $12 \mathrm{~h}$ after FGF23(R176Q) treatment, indicative of a late response gene. Our data strongly suggest a direct effect of FGF23 on PTH expression, although we cannot rule out the possibility that FGF23 may regulate $\mathrm{PTH}$ indirectly, by stimulating the release of other locally produced factor(s).

Notably, neither cell number nor viability or apoptosis was affected by treatment at high concentrations of FGF23(R176Q). A small but significant increase in cell proliferation was observed at $24 \mathrm{~h}$, although the biological significance of this finding is unclear. Our data support the assertion that FGF23 does not (a)

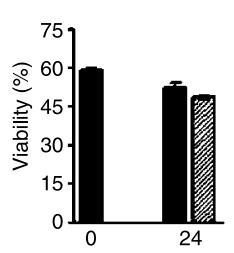

(b)

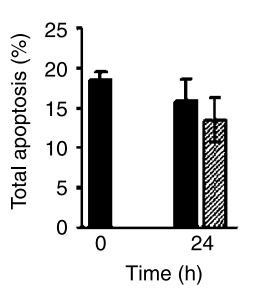

(c)

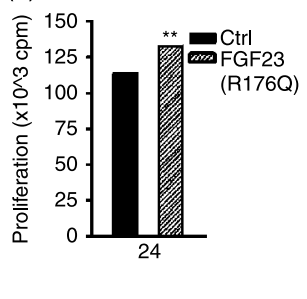

Figure 5 Effects of FGF23(R176Q) treatment on; (a) cell viability; (b) apoptosis; and (c) proliferation. No difference between FGF23(R176Q) and control-treated cells was observed with regard to cell viability and apoptosis, whereas a small increase in cell proliferation was noted. Cells were treated with $2000 \mathrm{pg} / \mathrm{ml}$ FGF23(R176Q). All measurements were performed after $24 \mathrm{~h}$ of FGF23(R176Q) treatment. ${ }^{* *} P<0 \cdot 01$. Error bars indicate mean \pm S.E.M. No error bars are seen in (c) due to small variability.

exert any major stimulatory or inhibitory growth effects on parathyroid cells in vitro at the short term. However, they suggest that the negative effect of FGF23(R176Q) on PTH expression is direct and independent of cell growth and/or survival.

In the present study, we used relatively high doses, i.e. 400-2000 pg/ml FGF23(R176Q) in order to observe effects on the PTH mRNA level or protein secretion. These concentrations are well above the reference range for healthy individuals (Yamazaki et al. 2002) and are typically found in subjects with ESRD (Larsson et al. 2003a) and some TIO and XLH patients (Jonsson et al. 2003). Our data may imply that FGF23 regulation of PTH is important in pathophysiology; however, they may also reflect typical in vivo/in vitro differences.

The in vitro system used in the present study provides a novel tool for the study of potential physiological actions of FGF23. However, a limitation of this system is that primary isolated parathyroid cells loose their ability to secrete PTH protein and display decreased PTH mRNA message over time, independent of FGF23 action. Therefore, one has to be careful when extrapolating our in vitro data into in vivo physiology. The presence of Klotho in parathyroid cells, as well as independent associations between serum FGF23 and PTH in early CKD (Shigematsu et al. 2004, Westerberg et al. 2007) are, however, suggestive of a physiological regulation of PTH by FGF23.

Since $1 \alpha(\mathrm{OH})$ ase is expressed in parathyroid glands (Segersten et al. 2002), we investigated the effect of FGF23(R176Q) on its mRNA transcript levels. Interestingly, FGF23(R176Q) dose-dependently increased $1 \alpha(\mathrm{OH})$ ase mRNA level. This indicates a differential regulation of $1 \alpha(\mathrm{OH})$ ase in kidneys and parathyroid glands, since FGF23 is known to potently and rapidly reduce renal expression of $1 \alpha(\mathrm{HO})$ ase (Shimada et al. 2001, 2002). The reason for this discrepancy is unclear, but may speculatively be an attempt of parathyroid glands to locally compensate for decreased serum calcitriol provoked by high circulating FGF23 levels. Further studies are needed to understand the differential expression and determine whether this has any functional importance in vivo. 
The etiology of secondary hyperparathyroidism in CKD is multifactorial, but involves alterations in mineral ion homeostasis. The combination of low $1,25(\mathrm{OH})_{2} \mathrm{D}_{3}$ and high $\mathrm{Pi}$ in $\mathrm{CKD}$ effectively triggers the production of $\mathrm{PTH}$, leading to a gradual development of parathyroid hyperplasia and elevated PTH levels (Fukagawa et al. 2006). Another implication of our study is a plausible role of FGF23 in secondary hyperparathyroidism of CKD, supported by recent studies (Bai et al. 2004, Larsson et al. 2004, Nakanishi et al. 2005). Our data may imply that FGF23, at least in part, has an inhibitory role in secondary hyperparathyroidism of CKD. In support, treatment with appropriate doses of calcitriol increases serum FGF23 (Collins et al. 2005, Ito et al. 2005, Nishi et al. 2005), while effectively preventing or postponing secondary hyperparathyroidism in CKD. In fact, one could speculate that the beneficial effects of calcitriol treatment in CKD may partly be attributed to an increase in FGF23. Of note, secondary hyperplastic glands and adenomas of hyperparathyroidism are phenotypically different when compared with normal parathyroid cells used in our in vitro system and could therefore respond differently to FGF23. Further studies are needed to clarify the role of FGF23 in secondary hyperparathyroidism.

In conclusion, FGF23(R176Q) is a negative regulator of PTH expression; however, it stimulates parathyroid $1 \alpha(\mathrm{OH})$ ase expression in vitro. Our data support the existence of a physiological skeletal-parathyroid endocrine axis and further provide insights into the complex regulation of calcium and Pi homeostasis.

\section{Acknowledgements}

We would like to thank Birgitta Bondeson, Peter Lillhager, and Signe Hässler for valuable technical assistance. This work was supported by the Novo Nordisk Foundation, the Swedish Kidney Foundation, and the Swedish Society of Medicine.

\section{Disclosure statements}

$\mathrm{T} E \mathrm{~L}$ and $\mathrm{O} \mathrm{Lj}$ receive consulting fees. All other authors have no conflicts of interest.

\section{References}

ADHR-Consortium 2000 Autosomal dominant hypophosphataemic rickets is associated with mutations in FGF23. Nature Genetics 26 345-348.

Bai X, Miao D, Li J, Goltzman D \& Karaplis AC 2004 Transgenic mice overexpressing human fibroblast growth factor 23 (R176Q) delineate a putative role for parathyroid hormone in renal phosphate wasting disorders Endocrinology 145 5269-5279.

Benet-Pages A, Orlik P, Strom TM \& Lorenz-Depiereux B 2005 An FGF23 missense mutation causes familial tumoral calcinosis with hyperphosphatemia. Human Molecular Genetics 14 385-390.
Collins MT, Lindsay JR, Jain A, Kelly MH, Cutler CM, Weinstein LS, Liu J, Fedarko NS \& Winer KK 2005 Fibroblast growth factor-23 is regulated by 1alpha,25-dihydroxyvitamin D. Journal of Bone and Mineral Research 20 1944-1950.

Feng JQ, Ward LM, Liu S, Lu Y, Xie Y, Yuan B, Yu X, Rauch F, Davis SI, Zhang S et al. 2006 Loss of DMP1 causes rickets and osteomalacia and identifies a role for osteocytes in mineral metabolism. Nature Genetics $\mathbf{3 8}$ 1310-1315.

Fukagawa M, Nakanishi S, Fujii H, Hamada Y \& Abe T 2006 Regulation of parathyroid function in chronic kidney disease (CKD). Clinical and Experimental Nephrology 10 175-179.

Gupta A, Winer K, Econs MJ, Marx SJ \& Collins MT 2004 FGF-23 is elevated by chronic hyperphosphatemia. Journal of Clinical Endocrinology and Metabolism 89 4489-4492.

Hoffman WH, Jueppner HW, Deyoung BR, O’Dorisio MS \& Given KS 2005 Elevated fibroblast growth factor-23 in hypophosphatemic linear nevus sebaceous syndrome. American Journal of Medical Genetics. Part A 134 233-236.

Imanishi Y, Inaba M, Nakatsuka K, Nagasue K, Okuno S, Yoshihara A, Miura M, Miyauchi A, Kobayashi K, Miki T et al. 2004 FGF-23 in patients with end-stage renal disease on hemodialysis. Kidney International 65 1943-1946.

Ito M, Sakai Y, Furumoto M, Segawa H, Haito S, Yamanaka S, Nakamura R, Kuwahata M \& Miyamoto K 2005 Vitamin D and phosphate regulate fibroblast growth factor-23 in K-562 cells. American Journal of Physiology and Endocrinological Metabolism 288 E1101-E1109.

Ito N, Fukumoto S, Taguchi M, Takeshita A, Takeuchi Y, Yamada S \& Fujita T 2007 Fibroblast growth factor (FGF) 23 in patients with acromegaly. Endocrine Journal 54 481-484.

Jonsson KB, Zahradnik R, Larsson T, White KE, Sugimoto T, Imanishi Y, Yamamoto T, Hampson G, Koshiyama H, Ljunggren O et al. 2003 Fibroblast growth factor 23 in oncogenic osteomalacia and X-linked hypophosphatemia. New England Journal of Medicine 348 1656-1663.

Kazama JJ, Sato F, Omori K, Hama H, Yamamoto S, Maruyama H, Narita I, Gejyo F, Yamashita T, Fukumoto S et al. 2005 Pretreatment serum FGF-23 levels predict the efficacy of calcitriol therapy in dialysis patients. Kidney International 67 1120-1125.

Knutson A, Hellman P, Akerstrom G \& Westin G 1998 Characterization of the human Megalin/LRP-2 promoter in vitro and in primary parathyroid cells. DNA and Cell Biology 17 551-560.

Kurosu H, Ogawa Y, Miyoshi M, Yamamoto M, Nandi A, Rosenblatt KP, Baum MG, Schiavi S, Hu MC, Moe OW, Moe OW et al. 2006 Regulation of fibroblast growth factor-23 signaling by klotho. Journal of Biological Chemistry 281 6120-6123.

Larsson T, Nisbeth U, Ljunggren O, Juppner H \& Jonsson KB $2003 a$ Circulating concentration of FGF-23 increases as renal function declines in patients with chronic kidney disease, but does not change in response to variation in phosphate intake in healthy volunteers. Kidney International 64 2272-2279.

Larsson T, Zahradnik R, Lavigne J, Ljunggren O, Juppner H \& Jonsson KB $2003 b$ Immunohistochemical detection of FGF-23 protein in tumors that cause oncogenic osteomalacia. European Journal Endocrinology 148 269-276.

Larsson T, Marsell R, Schipani E, Ohlsson C, Ljunggren O, Tenenhouse HS, Juppner H \& Jonsson KB 2004 Transgenic mice expressing fibroblast growth factor 23 under the control of the alpha1(I) collagen promoter exhibit growth retardation, osteomalacia, and disturbed phosphate homeostasis. Endocrinology 145 3087-3094.

Larsson T, Yu X, Davis SI, Draman MS, Mooney SD, Cullen MJ \& White KE 2005 A novel recessive mutation in fibroblast growth factor-23 causes familial tumoral calcinosis. Journal of Clinical Endocrinology and Metabolism 90 2424-2427.

Liu S, Guo R, Simpson LG, Xiao ZS, Burnham CE \& Quarles LD 2003 Regulation of fibroblastic growth factor 23 expression but not degradation by PHEX. Journal of Biological Chemistry 278 37419-37426.

Livak KJ \& Schmittgen TD 2001 Analysis of relative gene expression data using real-time quantitative PCR and the $2(-\Delta \Delta \mathrm{C}(\mathrm{T}))$ method. Methods 25 402-408.

Lorenz-Depiereux B, Bastepe M, Benet-Pages A, Amyere M, Wagenstaller J, Muller-Barth U, Badenhoop K, Kaiser SM, Rittmaster RS, Shlossberg AH 
et al. 2006 DMP1 mutations in autosomal recessive hypophosphatemia implicate a bone matrix protein in the regulation of phosphate homeostasis. Nature Genetics 38 1248-1250.

Mirams M, Robinson BG, Mason RS \& Nelson AE 2004 Bone as a source of FGF23: regulation by phosphate? Bone 35 1192-1199.

Nakanishi S, Kazama JJ, Nii-Kono T, Omori K, Yamashita T, Fukumoto S, Gejyo F, Shigematsu T \& Fukagawa M 2005 Serum fibroblast growth factor-23 levels predict the future refractory hyperparathyroidism in dialysis patients. Kidney International 67 1171-1178.

Nishi H, Nii-Kono T, Nakanishi S, Yamazaki Y, Yamashita T, Fukumoto S, Ikeda K, Fujimori A \& Fukagawa M 2005 Intravenous calcitriol therapy increases serum concentrations of fibroblast growth factor-23 in dialysis patients with secondary hyperparathyroidism. Nephron. Clinical Practice 101 c94-c99.

Riminucci M, Collins MT, Fedarko NS, Cherman N, Corsi A, White KE, Waguespack S, Gupta A, Hannon T, Econs MJ et al. 2003 FGF-23 in fibrous dysplasia of bone and its relationship to renal phosphate wasting. Journal of Clinical Investigation 112 683-692.

Segersten U, Correa P, Hewison M, Hellman P, Dralle H, Carling T, Akerstrom G \& Westin G 2002 25-Hydroxyvitamin D(3)-1alphahydroxylase expression in normal and pathological parathyroid glands. Journal of Clinical Endocrinology and Metabolism 87 2967-2972.

Shigematsu T, Kazama JJ, Yamashita T, Fukumoto S, Hosoya T, Gejyo F \& Fukagawa M 2004 Possible involvement of circulating fibroblast growth factor 23 in the development of secondary hyperparathyroidism associated with renal insufficiency. American Journal of Kidney Diseases 44 250-256.

Shimada T, Mizutani S, Muto T, Yoneya T, Hino R, Takeda S, Takeuchi Y, Fujita T, Fukumoto S \& Yamashita T 2001 Cloning and characterization of FGF23 as a causative factor of tumor-induced osteomalacia. PNAS $\mathbf{9 8}$ 6500-6505.

Shimada T, Muto T, Urakawa I, Yoneya T, Yamazaki Y, Okawa K, Takeuchi Y, Fujita T, Fukumoto S \& Yamashita T 2002 Mutant FGF23 responsible for autosomal dominant hypophosphatemic rickets is resistant to proteolytic cleavage and causes hypophosphatemia in vivo. Endocrinology 143 3179-3182.

Shimada T, Kakitani M, Yamazaki Y, Hasegawa H, Takeuchi Y, Fujita T, Fukumoto S, Tomizuka K \& Yamashita T 2004a Targeted ablation of Fgf23 demonstrates an essential physiological role of FGF23 in phosphate and vitamin D metabolism. Journal of Clinical Investigation 113 561-568.
Shimada T, Urakawa I, Yamazaki Y, Hasegawa H, Hino R, Yoneya T, Takeuchi Y, Fujita T, Fukumoto S \& Yamashita T 2004b FGF-23 transgenic mice demonstrate hypophosphatemic rickets with reduced expression of sodium phosphate cotransporter type IIa. Biochemical and Biophysical Research Communication 314 409-414.

Shimada T, Hasegawa H, Yamazaki Y, Muto T, Hino R, Takeuchi Y, Fujita T, Nakahara K, Fukumoto S \& Yamashita T 2004c FGF-23 is a potent regulator of vitamin D metabolism and phosphate homeostasis. Journal of Bone and Mineral Research 19 429-435.

Sitara D, Razzaque MS, Hesse M, Yoganathan S, Taguchi T, Erben RG, Juppner H \& Lanske B 2004 Homozygous ablation of fibroblast growth factor-23 results in hyperphosphatemia and impaired skeletogenesis, and reverses hypophosphatemia in Phex-deficient mice. Matrix Biology 23 421-432.

Urakawa I, Yamazaki Y, Shimada T, Ijima K, Hasegawa H, Okawa K, Fujita T, Fukumoto S \& Yamashita T 2006 Klotho converts canonical FGF receptor into a specific receptor for FGF23. Nature 444 770-774.

Westerberg PA, Linde T, Wikstrom B, Ljunggren O, Stridsberg M \&Larsson TE 2007 Regulation of fibroblast growth factor-23 in chronic kidney disease. Nephrology, Dialysis, Transplantation (In Press).

White KE, Carn G, Lorenz-Depiereux B, Benet-Pages A, Strom TM \& Econs MJ 2001a Autosomal-dominant hypophosphatemic rickets (ADHR) mutations stabilize FGF-23. Kidney International 60 2079-2086.

White KE, Jonsson KB, Carn G, Hampson G, Spector TD, Mannstadt M, Lorenz-Depiereux B, Miyauchi A, Yang IM, Ljunggren O et al. $2001 b$ The autosomal dominant hypophosphatemic rickets $(A D H R)$ gene is a secreted polypeptide overexpressed by tumors that cause phosphate wasting. Journal of Clinical Endocrinology and Metabolism 86 497-500.

Yamazaki Y, Okazaki R, Shibata M, Hasegawa Y, Satoh K, Tajima T, Takeuchi Y, Fujita T, Nakahara K, Yamashita Tet al. 2002 Increased circulatory level of biologically active full-length FGF-23 in patients with hypophosphatemic rickets/osteomalacia. Journal of Clinical Endocrinology and Metabolism $\mathbf{8 7}$ 4957-4960.

Received in final form 9 July 2007

Accepted 16 July 2007

Made available online as an Accepted Preprint 30 July 2007 